PART 1

The Law of the Sea and Ocean Governance 


\title{
Building a Platform for the Future: the Relationship of the Expected New Agreement for Marine Biodiversity in Areas beyond National Jurisdiction and the UN Convention on the Law of the Sea
}

\author{
Kristina M. Gjerde* \\ Senior High Seas Advisor, IUCN Global Marine and Polar Programme and \\ World Commission on Protected Areas, Cambridge, MA, USA

\begin{abstract}
Nichola A. Clark and Harriet R. Harden-Davies
Australian National Centre for Ocean Resources and Security, University of Wollongong, Australia
\end{abstract}

\begin{abstract}
[O]ur generation can take some pride in having contributed, no matter how fumblingly and bunglingly, to the making of the new order for the seas and oceans, to the opening of new ways of thinking about world order, and to the hammering-out of a platform from which in the future, a great many new initiatives can be launched. ${ }^{1}$

ELISABETH MANN BORGESE
\end{abstract}

\section{Introduction}

\section{Why Should We Care about Marine Biodiversity beyond National Jurisdiction?}

Marine areas beyond national jurisdiction (ABNJ), the high seas, and the International Seabed Area, comprise nearly two-thirds of the global ocean. ${ }^{2}$

* Dedicated to Elisabeth Mann Borgese, whose wisdom continues to shine as an inspiration for those seeking to follow in her footsteps. The authors would like to thank David Freestone, Duncan Currie, and our anonymous reviewers for their insightful comments.

1 E. Mann Borgese, "Foreword," San Diego Law Review 24, no. 3 (1987): 595, p. 601.

2 The "high seas" are "all parts of the sea that are not included in the exclusive economic zone, in the territorial sea or in the internal waters of a State, or in the archipelagic waters of an archipelagic State" (Article 86, UNCLOS). unCLOS Article 1 defines the "Area" as "[t]he seabed and ocean floor, and subsoil thereof, beyond the limits of national jurisdiction." 
Neither the high seas nor the Area belong to any single State; instead, under the framework of the United Nations Convention on the Law of the Sea (UNCLOS), ${ }^{3}$ these areas are managed through a suite of activity-specific agreements and global and regional bodies, each with their own mandates and priorities. ${ }^{4}$ The resulting governance structure has major gaps that undermine the possibilities for cooperation, coherence, and effective protection of the marine environment in ABNJ. ${ }^{5}$ Identified gaps in governance, regulation, and implementation include:

1. absence of an overarching set of governance principles for ecosystembased, science-based, precautionary approaches and open, inclusive, and transparent management;

2. a fragmented institutional framework lacking mechanisms for coordination across sectors or regions or for the incorporation of conservation concerns of international community interest;

3. lack of a global framework to establish a comprehensive system of marine protected areas or to promote other effective area-based conservation tools;

4. lack of global rules for environmental impact assessments of proposed projects or for strategic environmental assessments for proposed policies, programs, or activities;

5. limited capacity-building and technology transfer despite requirements in UNCLOS to enable developing States to study, protect and benefit from marine resources and the environment in $\mathrm{ABNJ}$;

6. legal uncertainty surrounding the status of marine genetic resources in ABNJ; and

7. uneven integration of marine environmental and biodiversity considerations into management and decision-making of sectoral organizations. ${ }^{6}$

3 United Nations Convention on the Law of the Sea, 10 December 1982, 1833 United Nations Treaty Series, 3. Entered into force 16 November 1994 [UNCLOS].

4 G. Wright, J. Rochette, K. Gjerde and I. Seeger, The Long and Winding Road: Negotiating a Treaty for the Conservation and Sustainable Use of Marine Biodiversity in Areas beyond National Jurisdiction, IDDRI Studies no. 08 (2018), p. 26, available online: <https://www.actuenvironnement.com/media/pdf/news-31928-iddri-haute-mer.pdf>.

5 K.M. Gjerde et al., Regulatory and Governance Gaps in the International Regime for the Conservation and Sustainable Use of Marine Biodiversity in Areas Beyond National Jurisdiction (Gland, Switzerland: IUCN, 2008), available online: <https://portals.iucn.org/library/sites/ library/files/documents/eplp-ms-1.pdf>. See also, R. Mahon et al., Transboundary Waters Assessment Programme (TWAP) Assessment of Governance Arrangements for the Ocean, Volume 2: Areas Beyond National Jurisdiction (Paris: UNESCO-IOC, IOC Technical Series 119, 2015), available online: $<$ http://onesharedocean.org/public_store/publications/ts119Vol2_eo.pdf >.

6 Gjerde et al., id.; Wright et al., n. 4 above. 
The lack of coherence in ABNJ management will impede achievement of global goals and needs for truly sustainable development of our one interconnected ocean. ${ }^{7}$ As highlighted in the first World Ocean Assessment:

The sustainable use of the ocean cannot be achieved unless the management of all sectors of human activities affecting the ocean is coherent. ... This requires taking into account the effects on ecosystems of each of the many pressures, what is being done in other sectors and the way that they interact. ${ }^{8}$

In response to rising concerns about the impacts of human activities on ocean health and the abundance, variety, and richness of marine life (biodiversity), ${ }^{9}$ the United Nations General Assembly (UNGA) has commenced negotiations for a new international legally binding instrument for the conservation and sustainable use of marine biodiversity in ABNJ under UNCLOS. ${ }^{10}$ The UNGA resolution launching negotiations (Resolution 72/249) sets out certain parameters for organizing discussions, including the need for the existing global regime to better address the conservation and sustainable use of marine biodiversity beyond national jurisdiction (BвNJ) and an understanding that the international legally binding instrument will take the form of a new implementing agreement to UNCLOS (BBNJ agreement), akin to the Part XI Agreement and the UN Fish Stocks Agreement (UNFSA). ${ }^{11}$ At the same time, it also states that

7 United Nations General Assembly (UNGA), "Summary of the First Global Integrated Marine Assessment," UN Doc. A/70/112 (22 July 2015), paras. 32-62. See also UNEP-wCMC, Marine Connectivity Across Jurisdictional Boundaries: An Introduction (Cambridge, UK: UN Environment World Conservation Monitoring Centre, 2018).

8 UNGA, id., para. 40.

9 For a history of the UN processes leading to the UNGA decision to launch negotiations, see K.M. Gjerde, "Perspectives on a developing regime for marine biodiversity conservation and sustainable use beyond national jurisdiction," in Ocean Law Debates: The 50Year Legacy and Emerging Issues for the Years Ahead, eds., H.N. Scheiber, N. Oral and M-S. Kwon, Law of the Sea Institute Publication (Boston: Brill Nijhoff, 2018), pp. 354-380; see also Wright et al., n. 4 above.

10 UNGA, "International legally binding instrument under the United Nations Convention on the Law of the Sea on the conservation and sustainable use of marine biological diversity of areas beyond national jurisdiction," UNGA Doc. A/RES/72/249 (24 December 2017) [72/249].

11 Agreement relating to the Implementation of Part XI of the United Nations Convention on the Law of the Sea of 10 December 1982, 28 July 1994, 1836 United Nations Treaty Series 3 (entered into force 28 July 1996) [Part XI Agreement]; Agreement for the Implementation of the Provisions of the United Nations Convention on the Law of the Sea of 10 December 1982 relating to the Conservation and Management of Straddling Fish Stocks and Highly 
the new instrument "should not undermine existing relevant legal instruments and frameworks and relevant global, regional and sectoral bodies."

The substance of the UN negotiations is set to address an agreed package of four issues: 1) marine genetic resources, including questions on the sharing of benefits; 2) measures such as area-based management tools (ABMTs), including marine protected areas (MPAS); 3) environmental impact assessments (EIAs); and 4) capacity-building and the transfer of marine technology. ${ }^{12}$ Cross-cutting issues such as guiding principles and institutional arrangements, as well as other traditional treaty provisions, are also key items for negotiators.

To assist in identifying ways to enhance coherence without undermining existing relevant legal instruments, frameworks, and bodies, this article addresses the potential relationship between the expected new BBNJ agreement and UNCLOS. In particular, it invokes the approaches used in a prior implementing agreement to UNCLOS, the UNFSA, to highlight ways the new agreement can improve implementation of the existing UNCLOS duties to protect and preserve the marine environment, conserve living marine resources, and cooperate for these purposes while incorporating modern conservation principles and tools. Marine genetic resources and options for benefit sharing, including through improved implementation of UNCLOS duties for cooperation on marine science, capacity-building, and marine technology transfer, are addressed in a sister article in this volume of the Ocean Yearbook. ${ }^{13}$

The first part of this article describes the provisions of UNCLOS most relevant to B BNJ and highlights the roles of other existing institutions and agreements. The second part describes how more recent agreements, principles, and commitments, including the 1992 Convention on Biological Diversity (СвD), ${ }^{14}$ can inform the substantive elements of the ввNJ agreement. The third part examines the key provisions of UNFSA as a potential model for the new BBNJ agreement and also identifies lessons to be learned. The fourth part examines institutional matters, specifically how to avoid undermining institutions and

Migratory Fish Stocks, 4 August 1995, 2167 United Nations Treaty Series 3 (entered into force 11 December 2001) [UNFSA].

$1272 / 249, n$. 10 above, para. 2. Focusing negotiations on a package of issues is as a tool for securing support to move forward together and as a whole on a range of issues so that no part of the agreement is considered "agreed" until all issues are addressed. This strategy was used during the UNCLOS negotiations (Wright et al., n. 4 above, p. 45).

13 H. Harden-Davies and K.M. Gjerde, "Building scientific and technological capacity: a role for benefit-sharing in the conservation and sustainable use of marine biodiversity beyond national jurisdiction," in Ocean Yearbook 33 (2019), in this volume.

14 Convention on Biological Diversity, 5 June 1992, 1760 United Nations Treaty Series 79 (entered into force 29 December 1993) [CBD]. 
agreements, and how new and improved institutional mechanisms can enhance cooperation and coordination. The fifth part concludes by highlighting some opportunities for the new BBNJ agreement to create a platform for more integrated, coherent, and ecosystem-based approaches to safeguarding marine life and the environment beyond national boundaries.

\section{Why is the New Agreement Important?}

Humankind depends upon the ocean. Global fish catches, critical to both food and economic security, total approximately 90 million tonnes. ${ }^{15}$ The international shipping industry carries approximately 90 percent of the world's trade, and submarine cables along the seafloor carry more than go percent of electronic communications. ${ }^{16}$ The International Seabed Authority (ISA) is in the process of developing exploitation regulations, which would enable the commercial exploitation of deep sea mineral resources of the Area, and the list of potential and emerging uses for the ocean, such as open ocean aquaculture, ocean fertilization, and even floating cities, continues to grow. ${ }^{17}$ Humans also benefit from the ecosystem services that the ocean provides - the ocean absorbs over one-quarter of the anthropogenic carbon dioxide emitted into the atmosphere, stores 93 percent of the resultant heat, and generates half of the oxygen we breathe. ${ }^{18}$ The ocean further serves as a place of adventure, inspiration, and imagination, even for those far from the sea.

The health of our ocean is declining. The 2018 report by the Food and Agriculture Organization of the United Nations (FAO) on The State of the World Fisheries and Aquaculture found that 93 percent of fish stocks are being fully or overexploited. ${ }^{19}$ This percent of maximally fished or overfished fish stocks has increased yet again, up from 90.1 percent in 2014 and 85 percent in $2010 .{ }^{20}$ Overfishing does more than reduce target fish stocks: it can deplete non-target species such as seabirds, sea turtles, and cetaceans, alter the genetic structure of fish stocks, change the relationships between predators and prey, and weaken

15 Food and Agriculture Organization of the United Nations (FAO), The State of World Fisheries and Aquaculture 2018 (Rome: FAO, 2018), p. 2, available online: <http://www.fao.org/3/ i9540en/I9540EN.pdf>.

16 International Chamber of Shipping, "Shipping and World Trade," available online: $<$ http:// www.ics-shipping.org/shipping-facts/shipping-and-world-trade>;UNGA,n.7 above, para. 2.

17 Gjerde et al., n. 5 above.

18 UNGA, n. 7 above, 3 , para. 1.

19 FAO, n. 15 above, p. 6.

20 FAO, The State of World Fisheries and Aquaculture 2014 (Rome: FAO, 2014), p. 7, available online: <http://www.fao.org/3/a-i372oe.pdf>; FAO, The State of World Fisheries and Aquaculture 2010 (Rome: FAO, 2010), p. 8, available online: <http://www.fao.org/3/a-i182oe.pdf>. 
the resilience of ecosystems to other impacts and environmental change. ${ }^{21}$ Fishing and other maritime activities can also degrade habitat by destroying fragile deep seabed communities, disrupt spawning, breeding, and nursery grounds, entangle and drown large marine animals in discarded fishing gear, and contaminate marine organisms throughout the food web with pollution, including from toxic heavy metals and microplastics. ${ }^{22}$

The direct effects of human activities are exacerbated by the impacts of rising carbon dioxide $\left(\mathrm{CO}_{2}\right)$ emissions. As the ocean stores evermore carbon, its waters become more acidic and less oxygenated, negatively impacting both the marine environment and the organisms residing therein. ${ }^{23}$ Ocean warming, acidification, and "dead zones" resulting from deoxygenation have been associated with each of the previous five mass extinction events on Earth, acting synergistically to change primary production patterns, alter species distribution and abundance, and impair reproduction and development. ${ }^{24}$ The cumulative impacts of these various activities threaten the health of the ocean by destabilizing ecosystems, disrupting food supplies, and undermining resilience to further impacts. ${ }^{25}$ The limited, often single-sector governance of these activities has not proved equal to the task of addressing these challenges.

\section{What's Next?}

In recognition of this growing concern about the health of marine ecosystems and biodiversity, governments agreed, in 2004, to study issues relating to the conservation and sustainable use of marine biological diversity in ABNJ. ${ }^{26}$ After nearly a decade of discussions, in 2015 the UNGA finally decided to establish a preparatory committee (PrepCom) to develop substantive recommendations on "elements of a draft text of an international legally binding

21 G. Ortuno Crespo and D.C. Dunn, "A review of the impacts of fisheries on open-ocean ecosystems," ICES Journal of Marine Science 74 (2018): 2283-2297; UNGA, n. 7 above, pp. 12-50, paras. 37, 78, 126, 136-137, and 195(b).

22 A. Eassom et al., Horizon Scan of Pressures on Biodiversity Beyond National Jurisdiction (Cambridge, UK: UNE P-WCMC 2016), p. 27, available online: <http://www.cambridgeconservation.org/sites/default/files/file-attachments/Horizon_Scan_v14_Final.pdf>.

23 UNGA, n. 7 above, para. 4.

24 A.D. Rogers and D. d'A. Laffoley, International Earth System Expert Workshop on Ocean Stresses and Impacts. Summary Report (Oxford: IPSo, 2011), pp. 5-6, available online: <http://www.stateoftheocean.org/wp-content/uploads/2015/10/2011-Summary-report_ workshop-on-stresses-and-impacts.pdf>.

25 Id., p. 6.

26 Wright, et al., n. 4 above; see also Gjerde, n. 9 above. 
instrument under the Convention."27 Two years later, and based upon the recommendations of the PrepCom, ${ }^{28}$ the UNGA passed Resolution 72/249 launching an intergovernmental conference to negotiate the new вв NJ agreement. ${ }^{29}$ The negotiations will be spread over four two-week sessions between September 2018 and September 2020. How the outcome of these negotiations can foster cooperation, coordination, and action at the global level as well as assist existing sectoral and regional bodies, other organizations, and States to better understand, manage, and adapt to the coming challenges of a changing ocean is what we turn to next. ${ }^{30}$

\section{The Existing Legal Basis for B BNJ}

\section{What UNCLOS Tells Us}

Widely recognized as the "constitution for the oceans," UNCLOS contains many provisions relevant to the conservation and sustainable use of marine biodiversity in ABNJ (see Table 1.1). Marine biodiversity is part of the watery realm of the marine environment and thus the starting point is Article 192 of UNCLOS, which clearly articulates that "States have the obligation to protect and preserve the marine environment." Article 194(5) of UNCLOS further requires that "measures taken [in accordance with Part XII on Protection and Preservation of the Marine Environment,] shall include those necessary to protect and preserve rare or fragile ecosystems as well as the habitat of depleted, threatened or endangered species and other forms of marine life."

As the International Tribunal for the Law of the Sea (ITLOS) recognized in the Southern Bluefin Tuna Cases, "the conservation of the living resources of the sea is an element in the protection and preservation of the marine

27 UNGA, "Development of an international legally binding instrument under the United Nations Convention on the Law of the Sea on the conservation and sustainable use of marine biological diversity of areas beyond national jurisdiction," UN Doc. A/RES/69/292 (19 June 2015) [69/292].

28 UNGA, "Report of the Preparatory Committee established by General Assembly resolution 69/292: Development of an international legally binding instrument under the United Nations Convention on the Law of the Sea on the conservation and sustainable use of marine biological diversity of areas beyond national jurisdiction," UN Doc. A/AC.287/2017/PC.4/2 (31 July 2017), pp. 8-9[PrepCom Report].

$2972 / 249$, n. 10 above.

30 The first two implementing agreements to UNCLOS are the Part XI Agreement and the UNFSA, see n. 11 above. 
TABLE 1.1 Key provisions in international law relevant for BBNJ Agreement

\section{Instrument Article Summary/excerpt of provision}

\begin{tabular}{|c|c|c|}
\hline UNCLOS & 117 & $\begin{array}{l}\text { States are obliged to take (or cooperate with other } \\
\text { States to take) "measures for their respective nation- } \\
\text { als as may be necessary for the conservation of the } \\
\text { living resources of the high seas." }\end{array}$ \\
\hline UNCLOS & 118 & $\begin{array}{l}\text { "States are obliged to cooperate with each other in } \\
\text { the conservation and management of living resourc- } \\
\text { es in the areas of the high seas" }\end{array}$ \\
\hline UNCLOS & 123 & $\begin{array}{l}\text { "States bordering an enclosed or semi-enclosed sea } \\
\text { should cooperate ... directly or through an appropriate } \\
\text { regional organization: (a) to coordinate the manage- } \\
\text { ment, conservation, exploration and exploitation of } \\
\text { the living resources of the sea; (b) to coordinate the } \\
\text { implementation of their rights and duties with respect } \\
\text { to the protection and preservation of the marine en- } \\
\text { vironment; (c) to coordinate their scientific research } \\
\text { policies ...; (d) to invite ... other interested States or } \\
\text { international organizations to cooperate with them in } \\
\text { furtherance of the provisions of this Article." }\end{array}$ \\
\hline UNCLOS & 192 & $\begin{array}{l}\text { Duty of States to protect and preserve the marine } \\
\text { environment. }\end{array}$ \\
\hline UNCLOS & $194(5)$ & $\begin{array}{l}\text { Measures taken to protect and preserve the marine } \\
\text { environment should include measures to protect rare } \\
\text { or fragile ecosystems or threatened or endangered } \\
\text { species. }\end{array}$ \\
\hline
\end{tabular}

$\begin{array}{lll}\text { UNCLOS } 197 \quad \begin{array}{l}\text { Duty of States to cooperate on a global basis and, } \\ \text { as appropriate, on a regional basis "in formulating } \\ \text { international rules, standards and recommended } \\ \text { practices and procedures ... for the protection and } \\ \text { preservation of the marine environment." }\end{array} \\ \text { UNCLOS 200 } & \begin{array}{l}\text { Duty of States to cooperate to promote studies, } \\ \text { research programs, and exchange of information and } \\ \text { data, with an aim of acquiring knowledge to assess } \\ \text { the "nature and extent of pollution." } \\ \text { Duty of States to cooperate in establishing appropri- } \\ \text { ate scientific criteria for the purposes of elaborating } \\ \text { rules and standards for the "prevention, reduction } \\ \text { and control of pollution of the marine environment." }\end{array}\end{array}$




\section{Instrument Article Summary/excerpt of provision}

\begin{tabular}{|c|c|c|}
\hline UNCLOS & 202 & $\begin{array}{l}\text { States shall promote scientific, educational, techni- } \\
\text { cal, and other programs to assist developing States } \\
\text { for the protection and preservation of the marine } \\
\text { environment; states shall provide assistance, espe- } \\
\text { cially to developing States, with respect to preparing } \\
\text { environmental assessments. }\end{array}$ \\
\hline
\end{tabular}

$\begin{array}{lcl}\text { UNCLOS } 203 \quad \begin{array}{l}\text { Developing States shall "be granted preference by } \\ \text { international organizations in: (a) the allocation of } \\ \text { appropriate funds and technical assistance; and } \\ \text { (b) the utilization of their specialized services." }\end{array} \\ \text { UNCLOS 204 } & \begin{array}{l}\text { Duty of States to "observe, measure, evaluate and } \\ \text { analyse ... the risks or effects of pollution of the } \\ \text { marine environment," in particular with respect to } \\ \text { activities under their jurisdiction. }\end{array} \\ \text { UNCLOS 205 } \quad \begin{array}{l}\text { Obligation of States to "publish reports of the results } \\ \text { obtained pursuant to Article 204" or provide them } \\ \text { to the competent international organizations; these } \\ \text { should be available to all States. }\end{array} \\ \text { UNCLOS } 206 \quad \begin{array}{l}\text { Duty of States to assess the potential effects of } \\ \text { planned activities on the marine environment if they } \\ \text { have reasonable grounds for believing those activities } \\ \text { may cause "substantial pollution of or significant and } \\ \text { harmful changes to the marine environment." States } \\ \text { are also obliged to communicate the results of that } \\ \text { assessment as outlined in Article 205. }\end{array}\end{array}$

$\begin{array}{lcl}\text { UNCLOS } 237 & \begin{array}{l}\text { Provisions are without prejudice to future agree- } \\ \text { ments related to the protection and preservation of } \\ \text { the marine environment. }\end{array} \\ \text { CBD } & 6 \quad \begin{array}{l}\text { Obliges Contracting Parties to "develop national } \\ \text { strategies, plans or programmes for the conservation } \\ \text { and sustainable use of biological diversity" and to } \\ \text { integrate "the conservation and sustainable use of } \\ \text { biological diversity into relevant sectoral or cross- } \\ \text { sectoral plans, programmes and policies." }\end{array} \\ \text { CBD } & \begin{array}{l}\text { Obliges Contracting Parties to "identify processes } \\ \text { and categories of activities which have or are likely to } \\ \text { have significant adverse impacts on the conservation } \\ \text { and sustainable use of biological diversity." }\end{array}\end{array}$


TABLE 1.1 Key provisions in international law relevant for BBNJ Agreement (cont.)

\section{Instrument Article Summary/excerpt of provision}

CBD

CBD

UNFSA

UNFSA

8

Obliges Contracting Parties to "establish a system of protected areas or areas where special measures need to be taken to conserve biological diversity," develop guidelines "for the selection, establishment and management of protected areas or areas where special measures need to be taken to conserve biological diversity," and to "regulate or manage biological resources important for the conservation of biological diversity whether within or outside protected areas, with a view to ensuring their conservation and sustainable use."

$\begin{array}{ll}\text { CBD } 14 & \begin{array}{l}\text { Obliges Contracting Parties to introduce measures } \\ \text { requiring environmental impact assessments of } \\ \text { proposed projects "that are likely to have significant } \\ \text { adverse impacts" on biodiversity, with a view to } \\ \text { avoiding or minimizing such effects. }\end{array} \\ & \begin{array}{l}\text { Articulates general principles to give effect to the } \\ \text { duty to cooperate, which includes the obligation to } \\ \text { "apply the precautionary approach" and to "protect } \\ \text { biodiversity in the marine environment." } \\ \text { Obliges states to "apply the precautionary approach } \\ \text { widely to conservation, management and exploita- } \\ \text { tion" of straddling and highly migratory fish stocks } \\ \text { "in order to protect the living marine resources and } \\ \text { preserve the marine environment." Also obliges } \\ \text { States to be "more cautious when information is un- } \\ \text { certain, unreliable or inadequate" and clarifies that } \\ \text { "the absence of adequate scientific information shall } \\ \text { not be used as a reason for postponing or failing to } \\ \text { take conservation and management measures." } \\ \text { Sets out provisions for ensuring compatibility of con- } \\ \text { servation and management measures and includes } \\ \text { an obligation for States to make every effort to agree } \\ \text { on compatible conservation and management mea- } \\ \text { sures within a reasonable period of time. }\end{array} \\ & \end{array}$




\section{Instrument Article Summary/excerpt of provision}

\begin{tabular}{lll}
\hline UNFSA & 8 & $\begin{array}{l}\text { Obliges States to consult when a proposed action } \\
\text { by one organization with competence over living } \\
\text { resources proposes a measure that would have a } \\
\text { significant effect on conservation and management } \\
\text { measures already established by an RFMo. }\end{array}$ \\
UNFSA & 14 & $\begin{array}{l}\text { Obliges States to "ensure that fishing vessels flying } \\
\text { their flag provide such information as may be neces- } \\
\text { sary in order to fulfill their obligations under this } \\
\text { Agreement." }\end{array}$
\end{tabular}

environment."31 Thus, the UNCLOS provisions recognizing the duty of all States to cooperate in the conservation and management of the living resources of the high seas (Articles 116-119) are also relevant. Article 119 elaborates upon the nature of the actions that States are required to take, including through application of the best scientific evidence available, care for associated and dependent species, and the sharing of catch statistics and other relevant data. ${ }^{32}$ However, implementation of these duties has largely focused on target fish stocks rather than living marine resources as a whole or the environment in which they are a part. ${ }^{33}$ Moreover, as described in Part III, it was due to the vagueness of these provisions and the continuing decline in shared fish stocks that States decided to negotiate a new implementing agreement that became the 1995 UNFSA. ${ }^{34}$

31 The Southern Bluefin Tuna cases (New Zealand v. Japan) (Australia v. Japan), IT Los Case Nos. 3 and 4, 27 August 1999, (1999) 38 International Legal Materials 1624, 1634, para. 70.

32 Article 119 obligations for cooperation including: (a) taking measures, "on the best scientific evidence available"; (b) taking measures to maintain or restore populations of species associated with, or dependent on, harvested species, so that they are not reduced to levels at which their reproduction may become seriously threatened; and (c) a general obligation to contribute and exchange on a regular basis, where appropriate, through subregional, regional or global organizations, available scientific information, catch and fishing effort statistics, and other data relevant to the conservation of fish stocks.

33 K.M. Gjerde et al., "Ocean in peril: Reforming the management of global ocean living resources in areas beyond national jurisdiction," Marine Pollution Bulletin 74 (2013):540-551. See "What Can Be Learned from UnFSA?" herein. 
With respect to the relationship with a new BвNJ agreement, Article 197 in UNCLOS specifically envisages and calls for the development of additional international rules, standards, and recommended practices and procedures to protect and preserve the marine environment. The text of Article 197 gives prominence to global cooperation, as well as the need to cooperate, as appropriate, on a regional basis, and to take into account "characteristic regional features." 35 Article 237 of UNCLOS provides further guidance by confirming that a new agreement may impose additional obligations with respect to the protection and preservation of the marine environment, provided they are carried out in a manner consistent with the general principles and objectives of the Convention. ${ }^{36}$ As is recalled in the Preamble to UnCLOs, such objectives include "the conservation of their living resources, and the study, protection and preservation of the marine environment." ${ }^{37}$ Action is to be premised on two pillars, due regard for the sovereignty of all States and recognition that "the problems of ocean space are closely interrelated and need to be considered as a whole."38

In addition to the substantive duty to protect and preserve the marine environment, Part XII's procedural and institutional mechanisms, intended to enable all States to implement these duties (via fostering capacity development and technology transfer, marine scientific research, and environmental assessments), similarly require further elaboration in the new ввNJ agreement. ${ }^{39}$ Other fundamental components of UNCLOS that are relevant to BBNJ but poorly implemented include more general provisions of Part XIII on marine scientific research, especially with respect to international cooperation, and Part XIV on the development and transfer of marine technology.

35 UNCLOS, n. 3 above, art. 197, which provides: "States shall cooperate on a global basis and, as appropriate, on a regional basis, directly or through competent international organizations, in formulating and elaborating international rules, standards and recommended practices and procedures consistent with this Convention, for the protection and preservation of the marine environment, taking into account characteristic regional features."

36 UNCLOs, id., art. 237, which provides: "1. The provisions of this Part are without prejudice to the specific obligations assumed by States under special conventions and agreements concluded previously which relate to the protection and preservation of the marine environment and to agreements which may be concluded in furtherance of the general principles set forth in this Convention. 2. Specific obligations assumed by States under special conventions, with respect to the protection and preservation of the marine environment, should be carried out in a manner consistent with the general principles and objectives of this Convention." (emphasis added).

37 UnCLOs, id., preamble, para. 4.

38 Id., preamble, para. 3.

39 See UNCLOS, id., Articles 204-206 on environmental assessments. 
The freedoms of the high seas recognized by Article 87 of UNCLOS are also highly relevant and serve as the basis of the high seas regime in UNCLOS. ${ }^{40} \mathrm{But}$ the exercise of such freedoms is subject to conditions laid down by the Convention, including the duty to protect and preserve the marine environment. ${ }^{41}$ As Long suggests, "States claiming rights under the Convention must assume correlative duties if the normative scheme is to work in practice."42 In practice, as a result of the sectoral approach reflected in UNCLOS, the adoption of protective measures for B BNJ has been left to States acting on an ad hoc basis through existing sector-based organizations where conservation is most often a secondary concern, not a primary focus. ${ }^{43}$ The interlinkages between activities and threats at the global and regional levels, the potential for increasing conflicts between activities such as deep-sea bottom fishing, seabed mining, and marine scientific research, and the need to protect international community interests in an increasingly crowded, degraded, and depleted ocean means that a more holistic, integrated and ecosystem approach is needed. ${ }^{44}$

As the fourth part of this article explores, among the key challenges to global ocean governance and в в $\mathrm{NJ}$ has been the absence of an institutional mechanism or specific rules, standards, and recommended practices and procedures to empower States to implement their duties to protect and conserve collectively through a non-sectoral lens at the global and, as appropriate, regional level. The UN negotiations for a new agreement on BBNJ thus provide an opportunity to create a platform for international cooperation and more coherent action to redress these gaps and weaknesses in an increasingly crowded, degraded, and depleted ocean.

\section{Other Relevant Organizations and Agreements}

In $A B N J$, other organizations exist and have an important role to play in the conservation and sustainable use of marine biodiversity in ABNJ. Regional fisheries management organizations (RFMOs) are responsible for managing high seas fish stocks. The International Seabed Authority (ISA) is responsible

40 The non-exhaustive list of high seas freedoms enumerated in Article 87 includes navigation, overflight, laying submarine cables and pipelines, fishing, and scientific research.

41 D. Freestone, "Modern principles of high seas governance: The legal underpinnings," Environmental Policy and Law 39(1) (2009): 44-49.

42 R. Long, "Marine science capacity building and technology transfer: Rights and duties go hand in hand under the 1982 UnCLOs," in Law, Science \& Ocean Management no. 11, eds., M. Nordquist et al. (Brill, 2007): 297-312.

43 D. Freestone, "The limits of sectoral and regional efforts to designate high seas marine protected areas," (2018) AJIL Unbound 112 (2018): 129-133, doi.org/10.1017/aju.2018.45.

44 Y. Tanaka, A Dual Approach to Ocean Governance: The Cases of Zonal and Integrated Management in International Law of the Sea (Ashgate, 2008) (London: Routledge 2016), p. 7 . 
for regulating exploration and exploitation of the mineral resources of the Area pursuant to Part XI of UNCLOS and the 1994 Implementing Agreement.45 The International Maritime Organization (IMO) adopts conventions and other regulations governing international shipping and dumping. ${ }^{46}$ The Intergovernmental Oceanographic Commission (IOC) of the United Nations Educational, Scientific and Cultural Organization (UNESCO) promotes international cooperation and coordinates programs in marine research, services, observation systems, hazard mitigation, and capacity development to understand and manage ocean and coastal resources. ${ }^{47}$

A number of global level, species-oriented conservation agreements are in place, including the International Convention on the Regulation of Whaling (IWC), the Convention on International Trade in Endangered Species of Wild Fauna and Flora (CiTES), and the Convention on Migratory Species (CMS). ${ }^{48}$ The CMS encourages States to develop further agreements on species of concern, such as the Agreement on the Conservation of Albatrosses and Petrels and the Memorandum of Understanding on the Conservation of Sharks that may apply regionally or globally. ${ }^{49}$ The shortcomings of the species-specific approach led to the negotiation of the $\mathrm{CBD}$, but as is explored in the following part of this article, the СBD drafters opted to focus primarily on the components of biodiversity in areas within national jurisdiction, leaving a gap for marine species and their habitats in ABNJ.

At the regional level, four regional seas organizations already have an explicit geographic mandate which includes $\mathrm{ABNJ},{ }^{50}$ and several others, including the

45 Part XI Agreement, n. 11 above.

$46 \quad 1996$ London Protocol to the 1972 Convention on the Prevention of Marine Pollution by Dumping of Wastes and Other Matter, 7 November 1996, 36 International Legal Materials 1 (1997) (entered into force 24 March 2006).

47 Unesco, "About the Intergovernmental Oceanographic Commission," available online: $<$ http://www.unesco.org/new/en/natural-sciences/ioc-oceans/about-us/>.

48 International Convention for the Regulation of Whaling, 1946 (entry into force 1948); Convention on International Trade in Endangered Species of Wild Fauna and Flora, 1973 (entry into force 1975); Convention on the Conservation of Migratory Species of Wild Animals, 1979, (entry into force 1983) [CMS].

49 Agreement on the Conservation of Albatrosses and Petrels (2001) (entry into force 2004), available online: <https:/www.acap.aq/>; Memorandum of Understanding on the Conservation of Sharks (2010, amended 2016), available online: <https://www.cms.int/ sharks/>.

50 Convention for the Protection of the Marine Environment and the Coastal Region of the Mediterranean, 1976, amended 1995 (entry into force 1978, and amendments in 2004); Convention on the Conservation of Antarctic Marine Living Resources, 1980 (entry into force 1982); Convention for the Protection of the Marine Environment of the North-East Atlantic, 1992 (entry into force 1998); Convention for the Protection of the Natural Resources and Environment of the South Pacific Region, 1986 (entry into force 1990). 
Permanent Commission for the South Pacific, the Abidjan Convention in the Southeast Atlantic, and the Nairobi Convention in the Western Indian Ocean, are exploring options for extending their governance efforts to ABNJ. ${ }^{51} \operatorname{In} 2016$, the United Nations Environment Assembly (UNEA) of UN Environment adopted a resolution that encouraged parties to regional seas conventions to consider the possibility of increasing the regional coverage of those instruments in accordance with international law. ${ }^{52}$

However, in terms of cross-sectoral cooperation for integrated management or conserving biodiversity, there are wide discrepancies between regions. ${ }^{53}$ This has left some regions with much more powerful governance mechanisms than others and considerable differences in funding, causing competitive (dis)advantages between regions and an absence of a level playing field at the global level. ${ }^{54}$ This is translating into a frequent inability to effectively protect transboundary species and ecosystems or deal with transboundary impacts from bordering regions with less stringent regulations. As noted in Billé et al., "Strong efforts in just a few regions will still not prevent loss of marine biodiversity at the global level." 55

It is against this backdrop that this article investigates how the BвNJ agreement can address this uneven implementation at the sectoral and regional levels by galvanizing action through new global level rules, standards, and recommended practices and procedures to be implemented by States parties to the new BBNJ agreement both directly and through competent global and regional bodies of which they are members. In this manner the new вBNJ agreement can support and not undermine existing instruments, frameworks or bodies.

\section{Building on UNCLOS}

\section{Towards Integrated Approaches to Conserving Marine Biodiversity in $A B N J$ : Learning from the $C B D$}

The need to supplement UNCLOS with new approaches, principles, and mechanisms was already apparent in 1992 when the United Nations Conference on Environment and Development (UNCED) in Rio de Janeiro adopted Chapter 17

\footnotetext{
$5^{1} \quad$ Wright et al., n. 4 above.

52 UN Environment Assembly of the UN Environment Programme, "Oceans and Seas," Second session, 23-27 May 2016, UN Doc. UNEP/EA.2/Res.10 (4 August 2016), para. 13.

53 Mahon et al., n. 5 above.

54 R. Billé et al., Regional Oceans Governance: Making Regional Seas Programmes, Regional Fishery Bodies and Large Marine Ecosystem Mechanisms Work Better Together, UNEP Regional Seas Reports and Studies No. 197 (UnEP Regional Seas Programme, 2016), p. 6 o. Id.
} 
of Agenda 21, which called for more integrated, anticipatory, and precautionary approaches to ocean management and governance. ${ }^{56}$ The $\mathrm{CBD}$, also adopted at UNCED, was the first instrument to explicitly call on States to incorporate biodiversity conservation goals as a priority into governmental policies and management measures. As the CBD now has 196 States parties, it represents a near universal commitment to conserve and sustain biodiversity wherever it is found. Although the СвD is limited in its applicability to вв ${ }^{5},{ }^{57}$ here we explore how СвD provisions can nevertheless inform the substance of new rules, standards, and recommended practices and procedures for the ввNJ agreement with respect to area-based management tools and EIAs in a manner that is consistent with the principles and objectives of UNCLOS.

As a starting point, it is important to note that the СвD Preamble recognizes both the "intrinsic value" of biodiversity as well as the "ecological, genetic, social, economic, scientific, educational, cultural, recreational and aesthetic values of biological diversity and its components, including its importance for evolution and for maintaining life sustaining systems of the biosphere." 58 In affirming that the conservation of biological diversity is a "common concern of humankind," the СвD seeks to bring States and peoples together in common cause to support conservation efforts both within and beyond national jurisdiction. ${ }^{59}$ It further underscores the need to value, conserve, and sustain biodiversity, despite often competing short-term economic drivers, if we are to maintain the life-sustaining systems of the biosphere.

The CBD includes a specific reference to its relationship with UNCLOS. Article 22(2) clarifies that the provisions of the СвD with respect to the marine environment should be implemented "consistently with the rights and obligations of States under the law of the sea." Interestingly, Article 22(1) of the СвD also provides that " $[\mathrm{t}]$ he provisions of this Convention shall not affect the rights and obligations of any Contracting Party deriving from any existing international agreement, except where the exercise of those rights and obligations

$56 \quad$ "1992 Agenda 21," Chapter 17.01 in S. Johnson, The Earth Summit (London: Kluwer, 1992), p. 307 .

57 Although the text in the CBD, n. 14 above, expressly limits application of the Convention's provisions on components of biodiversity to areas within the limits of national jurisdiction (Article 4(a)), it nevertheless, in Article 4(b) states that the provisions of the Convention apply "in the case of processes and activities, regardless of where their effects occur, carried out under its jurisdiction or control, within the area of its national jurisdiction or beyond the limits of national jurisdiction" (emphasis added).

$5^{8}$ Id., preamble.

59 Article 5, id., calls for Contracting Parties to cooperate directly and, where appropriate, through competent international organizations in respect of ABNJ and other matters of mutual interest. 
would cause a serious damage or threat to biological diversity" (emphasis added). This suggests that there could indeed be instances where a threat of serious damage to biodiversity could impel immediate action even if such action affected the rights of States under UNCLOs, but this has not been tested. At any rate, many of the $\mathrm{CBD}$ provisions that apply to processes and activities under State jurisdiction and control are already applicable to ABNJ, but as with UNCLOS, the new BвNJ agreement may provide a more robust vehicle for their implementation.

In terms of how to conserve biodiversity, the СвD starts from the basic observation in its Preamble that "the fundamental requirement for the conservation of biological diversity is the in-situ conservation of ecosystems and natural habitats and the maintenance and recovery of viable populations of species in their natural surroundings." 60 It is more than just the establishment of protected areas and thus requires action across all sectors and regions.

Article 6 of the СвD provides an example of a way to encourage biodiversity action at the sectoral level without affecting existing mandates by calling for parties to take two broad-ranging actions: i) develop national strategies, plans, or programs to reflect the measures set out on the Convention; and ii) "integrate, as far as possible and as appropriate, the conservation and sustainable use of biodiversity into relevant sectoral or cross sectoral plans, programmes and policies." ${ }^{\prime 1}$ The в BNJ agreement could similarly call for States to adopt national biodiversity strategies that include ways to reduce biodiversity impacts of activities and processes in ABNJ under national jurisdiction and control, and to promote the development of similar sectoral and cross-sectoral plans, programs, and policies.

With respect to area-based management tools, CBD Article 8 on In-situ Conservation underscores the need for both MPAs as well as other special measures, including sector-based measures, to conserve biodiversity. ${ }^{62}$ Of particular relevance, Article 8 calls for States to, among other things, (a) establish a system of protected areas or areas where special measures need to be taken to conserve biological diversity; (b) develop guidelines for the selection, establishment and management of protected areas or areas where special measures need to be taken to conserve biological diversity; (c) regulate or manage biological resources important for the conservation of biological diversity, whether within or outside protected areas, with a view to ensuring their conservation and sustainable use; (d) promote the protection of ecosystems, natural habitats, and

\footnotetext{
$60 \quad$ Id., preamble.

61 Id., art. 6.

62 Id., art. 8.
} 
the maintenance of viable populations of species in their natural surroundings; and (e) promote environmentally sound and sustainable development in areas adjacent to protected areas with a view to furthering the protection of these areas. All of these measures would usefully support the integration of biodiversity concerns into sectoral activities affecting BBNJ.

With respect to environmental impact assessments, the СвD sets forth a more precautionary threshold and a more explicit obligation to avoid harm than Article 206 of UnCLOS (substantial pollution or significant and harmful changes). Article 14 of the CBD calls for EIAs of proposed projects "that are likely to have significant adverse impacts" on biodiversity, with a view to avoiding or minimizing such effects. ${ }^{63}$ The CBD explicitly calls for strategic environmental assessments (SEAS) to ensure that environmental consequences of programs and policies likely to have a significant adverse impact on biodiversity are duly taken into account. SEAs are a concept discussed but not yet embraced in the UN вBNJ discussions that could provide an important regional or ecosystem-level perspective. The СвD extends the UNCLOS obligation for monitoring the risks or effects of pollution (Article 204) to include the proactive identification and ongoing monitoring of any activity or process which has or is likely to have "significant adverse impacts on conservation and sustainable use of biodiversity." ${ }^{4}$ Similar provisions in the BBNJ agreement could extend the benefits of EIAs and SEAs far beyond the planning stage.

The СвD Conference of Parties (СOP) has already contributed to the scientific and technical basis for action to conserve BвNJ. While recognizing the central role of the UNGA in addressing issues relating to the conservation and sustainable use of marine biodiversity in $\mathrm{ABNJ},{ }^{65}$ the СBD COP has developed a scientific process to describe "ecologically or biologically significant marine areas" (EBSAS) and voluntary guidelines for the consideration of marine biodiversity in EIAS and SEAS in ABNJ. ${ }^{66}$ To encourage action, CBD COP Decision 10/29 requested States and competent international organizations to consider enhancing EBSA protection and management, including through measures

\footnotetext{
63 Id., art. 14.

64 Id., art. 7 .

65 СвD Decision X/29,"Marine and Coastal Biodiversity” (2010), para. 24.

66 СвD, "Marine and Coastal Biodiversity: Revised Voluntary Guidelines for the Consideration of Biodiversity in Environmental Impact Assessments and Strategic Environmental Assessments in Marine and Coastal Areas," Doc. UNEP/CBD/COP/11/23 (21 August 2012). СвD voluntary guidelines for the consideration of biodiversity in environmental impact assessments and strategic environmental assessments annotated specifically for biodiversity in marine and coastal areas, including in areas beyond national jurisdiction, in accordance with Article 4 of the Convention.
} 
such as MPAs and EIAs. ${ }^{67}$ The BBNJ agreement offers an opportunity to build on this important work.

\section{Deeper Commitments and a Timeline for Action: Rio +25}

The 25-plus years since Rio have underscored the need for international collaboration and action for BBNJ. Marine biodiversity in ABNJ has been on the international agenda since at least 2002. At the World Summit on Sustainable Development (WSSD), Australia proposed, and WSSD adopted, text calling on the international community to "maintain the productivity and biodiversity of important and vulnerable marine and coastal areas, including in areas within and beyond national jurisdiction." 68 This call was complemented by a more elaborate call for action at all levels to

[d]evelop and facilitate the use of diverse approaches and tools, including the ecosystem approach, the elimination of destructive fishing practices, the establishment of marine protected areas consistent with international law and based on scientific information, including representative networks by 2012, time/area closures for the protection of nursery grounds and spawning periods and the integration of marine areas management into key sectors. ${ }^{69}$

The WSSD commitments were reinvigorated at the 2012 United Nations Conference on Sustainable Development (Rio+2o), where the Heads of States and Government agreed to commit to "protect the health, productivity and resilience of the marine environment, and to maintain its biodiversity," including through ecosystem approaches and precaution, on behalf of present and future generations. ${ }^{70}$ This commitment was further elaborated on in UN Sustainable

67 Свр Decision x/29/, n. 65 above, para. 24.

68 United Nations, "Report of the World Summit on Sustainable Development, Resolution 2, Plan of Implementation of the World Summit on Sustainable Development, Johannesburg, South Africa, 26 August-4 September 2002," (New York: United Nations, 2002), UN Doc. A/Conf.199/20, annex, p. 24, para. 32(a).

69 Id., para. 32(c).

$70 \quad$ UNGA, "The Future We Want," UN Doc. A/RES/66/288 (11 September 2012), para. 158. ("We [the Heads of State and Government and high-level representatives] recognize that oceans, seas and coastal areas form an integrated and essential component of the Earth's ecosystem and are critical to sustaining it, and that international law, as reflected in the United Nations Convention on the Law of the Sea, provides the legal framework for the conservation and sustainable use of the oceans and their resources. We stress the importance of the conservation and sustainable use of the oceans and seas and of their resources for sustainable development, including through their contributions to poverty 
Development Goal (SDG) 14, which highlights the conservation and sustainable use of the ocean as one of the world's most pressing global sustainability challenges. ${ }^{71}$ Specifically, SDG target 14.2 commits States to "sustainably manage and protect marine and coastal ecosystems to avoid significant adverse impacts, including strengthening their resilience, and take action for their restoration in order to achieve healthy and productive oceans, by 2020." Adoption of a strong BBNJ agreement by 2020 would be an important step to reset the course for ocean health and resilience. How this might be done is what we turn to next.

\section{What Can Be Learned from UNFSA?}

\section{Historical Context and Relationship to UNCLOS}

As one of two implementing agreements to UNCLOS, ${ }^{72}$ the UNFSA provides an illuminating example of crafting a relationship with UNCLOS that respects existing institutions but also significantly advances the status quo. Like the BBNJ agreement, UNFSA was developed in the context of an array of existing institutions as well as many geographic and management gaps. ${ }^{73} \mathrm{~A}$ major concern was "to avoid the development of disparate practices in different subregions or regions" while taking into account the circumstances prevailing in the different regions and the nature of the different fish stocks. ${ }^{74}$ As discussed

eradication, sustained economic growth, food security and creation of sustainable livelihoods and decent work, while at the same time protecting biodiversity and the marine environment and addressing the impacts of climate change. We therefore commit to protect, and restore, the health, productivity and resilience of oceans and marine ecosystems, to maintain their biodiversity, enabling their conservation and sustainable use for present and future generations, and to effectively apply an ecosystem approach and the precautionary approach in the management, in accordance with international law, of activities having an impact on the marine environment, to deliver on all three dimensions of sustainable development.") This commitment applies to marine areas within and beyond national jurisdiction.

71 UNGA, "Transforming Our World: The 2030 Agenda for Sustainable Development," UN Doc. A/RES/70/1 (21 October 2015), Goal 14: Life Below Water, available online: <http:// www.undp.org/content/undp/en/home/sustainable-development-goals/goal-14-life-below-water.html>.

72 The 1994 Part XI Agreement had a different purpose, securing developed country participation in UNCLOS to enable UNCLOS to come into force, and thus is not the subject of this discussion. See $n .11$ above.

73 UNGA, "A Guide to the Issues Before the Conference Prepared by the Chairman," UN Doc. A/CONF.164/10 (24 June 1993), para. 13.II(c) [Conference Chairman]. Id. 
below, the UNFSA built a complex architecture that relies on a mix of general principles, specific obligations giving effect to the duty to cooperate, and detailed guidance for regional management institutions. But whether it went far enough is the subject of debate: while UNFSA succeeded in raising the standards for regional fisheries management, the performance of those organizations has varied widely; fishing effort is still on the rise and the remaining fish stocks are still declining. ${ }^{75}$

It may be helpful to recall the historical context that precipitated the UNFSA. As noted in UNFSA's Preamble: "the management of high seas fisheries is inadequate in many areas and that some resources are overutilized; noting that there are problems of unregulated fishing, over-capitalization, excessive fleet size, vessel reflagging to escape controls, insufficiently selective gear, unreliable databases and lack of sufficient cooperation between States." Responding to strong concerns about ecosystem and biodiversity impacts of fishing activities, the Preamble also reflects that the drafters were: "[c]onscious of the need to avoid adverse impacts on the marine environment, preserve biodiversity, maintain the integrity of marine ecosystems and minimize the risk of longterm or irreversible effects of fishing operations."

The negotiators of UNFSA were charged with filling gaps where there were no management organizations, but also with improving existing management operations. Their goal was to develop practical means to give effect to the provisions of the Convention, including the duty of cooperation, and, in so doing, empower and structure RFMOs as the primary vehicle for effective long-term regional and sub-regional fisheries management, encourage States in existing RFMOS to review their cooperation mechanisms, recognize the aspirations of new entrants, raise the capacity of developing countries globally, and ensure more consistent standards for enforcement. ${ }^{76}$

The relationship of UNFSA to UNCLOS is spelled out in a straightforward way in both UnFSA Article 2 on "the Objective" and Article 4 entitled "Relationship between this agreement and the Convention." Article 2 provides: "The objective of this Agreement is to ensure the long-term conservation and sustainable use of straddling fish stocks and highly migratory fish stocks through effective implementation of the relevant provisions of the Convention." Article 4 provides that "[n]othing in this Agreement shall prejudice the rights, jurisdiction and duties of States under the Convention. This Agreement shall be interpreted and applied in the context of and in a manner consistent with the Convention."

75 Gjerde et al., n. 33 above.

76 Conference Chairman, n. 73 above. 
Such text acknowledges the legal framework of UNCLOS, recognizing that rights such as freedom of fishing, State jurisdiction over specific zones such as the exclusive economic zone (EEZ) and continental shelf, and duties to conserve, cooperate, and control flag vessels, remain intact.

The final report of the ввNJ PrepCom draws inspiration from Article 4 of UNFSA when suggesting how the new BBNJ agreement could describe its relationship to UNCLOS and other instruments and frameworks and relevant global, regional, and sectoral bodies:

With regard to the relationship to the Convention, the text would state that nothing in the instrument shall prejudice the rights, jurisdictions and duties of States under the Convention. It would further state that the instrument shall be interpreted and applied in the context of and in a manner consistent with the Convention. ${ }^{77}$

The PrepCom report continues with a suggestion that text on the relationship of the BвNJ agreement to the Convention and other instruments would "promote greater coherence with and complement" existing bodies and instruments. ${ }^{78}$

The "President's Aid to Discussions" circulated by the President of the Intergovernmental Conference (IGC) to guide the discussions during the first IGC session does not suggest any text that could be considered under a section dealing with the BBNJ agreement's relationship to the Convention and other instruments, but it does pose multiple questions, under each of the four package elements, that would lead to possible text that could be considered. ${ }^{79}$

77 PrepCom Report, n. 28 above, pp. 8-9.

78 Id.

79 UNGA, "President's Aid to Discussions," First substantive session of the Intergovernmental Conference on an international legally binding instrument under the United Nations Convention on the Law of the Sea on the conservation and sustainable use of marine biological diversity of areas beyond national jurisdiction, UN Doc. A/CONF.232/2018/3 (25 June 2018): The topic "relationship to the Convention and other instruments and frameworks and relevant global, regional and sectoral bodies" appears in every subsection of the President's Aid to Discussion, with questions tailored to that specific element. So, for example, under para. 4.2, which deals with area-based management tools, it says: "(a) The manner in which the instrument would set out the relationship between measures under the instrument and measures under existing relevant legal instruments and frameworks and relevant global, regional and sectoral bodies. (b) The provisions that would be included to address issues of compatibility between measures under the instrument and those established by adjacent coastal States. Would the provisions include, for example, provisions for the sharing of information and/or for consultation? (c) The manner in which the instrument would reflect respect for the rights of coastal States over all areas 


\section{States Parties Powers to Adopt Stronger Measures}

One of the critical items for negotiators of the B BNJ agreement to determine is where the power to implement area-based management tools, including M PAs, should rest. As further explored below under "Building a Platform for Cooperation for BBNJ ," some argue that management authority should reside solely in RFMOS and other existing sectoral bodies, while others assert the need for more global control noting that States have the inherent power to adopt stronger measures amongst themselves so long as they are not less effective than existing regulations. This inherent power to adopt additional measures or agreements is recognized in Article 44 of UNFSA, which acknowledges that States parties may conclude agreements modifying or suspending operation of provisions of UNFSA under three conditions, and upon notification of other States parties. ${ }^{80}$

According to Article 44, States parties to UNFSA retain the power to take more stringent measures so long as any actions taken thereunder are 1) compatible with the object and purposes of UNFSA and UNCLOS, i.e., support the long-term conservation of fish stocks and the protection of the marine environment, 2) do not affect the application of the basic principles embodied in the Convention or the Agreement, and 3) do not affect the enjoyment by other States parties of their rights or performance of their obligations. Article 44 of UNFSA may thus provide a helpful model for the BBNJ agreement as it reflects the inherent powers of States under international law to take actions among themselves that may be more stringent than those made by other organizations or pursuant to other agreements without undermining existing agreements or bodies. Such a provision would not replace RFMOs or other sectoral organizations but would enable States parties to the ввNJ agreement to take more rapid and direct action while they seek to promote comparable measures

under their national jurisdiction, including the continental shelf within and beyond 200 nautical miles and the exclusive economic zone."

8o Article 44(1) provides that "this Agreement shall not alter the rights and obligations of States Parties which arise from other agreements compatible with this Agreement and which do not affect the enjoyment by other States Parties of their rights or the performance of their obligations under this Agreement;" Article 44(2) provides that "[t]wo or more States Parties may conclude agreements modifying or suspending the operation of provisions of this Agreement, applicable solely to the relations between them, provided that such agreements do not relate to a provision derogation from which is incompatible with the effective execution of the object and purpose of this Agreement, and provided further that such agreements shall not affect the application of the basic principles embodied herein, and that the provisions of such agreements do not affect the enjoyment by other States Parties of their rights or the performance of their obligations under this Agreement." 
through the relevant sectoral organizations and enable States parties to take coherent measures across sectors and regions.

\section{Application of the Term "Undermine"}

UNFSA can also provide guidance to those seeking to understand the term "not undermine" in the context of в BNJ. The use of the term "undermine" in UNFSA is applied in the very limited context of "undermine the effectiveness of" (see Table 1.2). In other words, UNFSA uses the term "undermine" to mean to undercut or make less effective.

UNFSA also envisages that States may adopt global conservation and management measures in addition to regional measures, which suggests that conservation measures would be adopted by organizations other than the (regional) RFMOs without undermining them. For example, Article 20(4) of UNFSA calls for States to assist each other in reporting on vessels engaged in undermining the effectiveness of global as well as subregional and regional conservation and management measures. In fact, there are positive ways to refer to "not undermine" that could assist in the enforcement of regional measures at the global level, as well as any measures adopted pursuant to the вв $\mathrm{NJ}$ agreement. Article 33(2), for example, which refers to measures with respect to non-parties to the agreement, calls for States parties to take measures consistent with UNFSA and international law to "deter the activities of vessels flying the flag of non-parties which undermine the effective implementation of this Agreement," a reference to measures that would be less effective in managing and conserving relevant fish stocks and associated species and ecosystems. A similar provision in the BBNJ agreement could provide clarity on enforcement.

\section{Influencing Existing Organizations without Undermining Them}

UNFSA also helps to address the question of how the new agreement can influence the way existing organizations operate without "undermining" them. There are six key ways that UNFSA elaborates on the duty of cooperation:

1. General Principles to Give Effect to the Duty to Cooperate

Article 5 articulates general principles through which States are to give effect to their duty to cooperate. The first of a long list of principles gives effect to the central objective of the Agreement: "(a) adopt measures to ensure long-term sustainability of straddling fish stocks and highly migratory fish stocks." But Article 5 also elaborates on other elements that are to be "ensured," "applied," and "assessed" and measures "adopted" for other species at the same time. The degree of specificity varies greatly, from the very general: "protect biodiversity in the marine environment," in Article 5(g), to the very specific and operational: 
TABLE 1.2 "Undermine" in the UN Fish Stocks Agreement

Article Summary/Excerpt of Provision

Article 7(2)(a) States shall ensure that conservation measures for straddling fish stocks in the high seas "do not undermine the effectiveness" of measures adopted for the same stocks within a coastal State's EEZ.

Article 16(2) "States concerned shall take measures in respect of vessels flying their flag in order that they not engage in fisheries which could undermine the stocks concerned."

Article 17(4) States "shall take measures consistent with this Agreement and international law to deter activities of such vessels which undermine the effectiveness of subregional or regional conservation and management measures."

Article 18(1) Flag States shall "take such measures as may be necessary to ensure that vessels flying its flag comply with subregional and regional conservation and management measures and that such vessels do not engage in any activity which undermines the effectiveness of such measures."

Article 18(3)(h) Flag States shall take measures in respect to vessels flying its flag to regulate "transshipment on the high seas to ensure that the effectiveness of conservation and management measures is not undermined."

Article 20(4) "States shall assist each other in identifying vessels reported to have engaged in activities undermining the effectiveness of subregional, regional or global conservation and management measures."

Article 20(7) RFMO member States may take action "to deter vessels which have engaged in activities which undermine the effectiveness of or otherwise violate the conservation and management measures established by that organization."

Article 23(3) "States may adopt regulations empowering the relevant national authorities to prohibit landings and transshipments where it has been established that the catch has been taken in a manner which undermines the effectiveness of subregional, regional or global conservation and management measures on the high seas."

Article 33(2) "States Parties shall take measures consistent with this Agreement and international law to deter the activities of vessels flying the flag of non-Parties which undermine the effective implementation of this Agreement." 
"adopt, where necessary, conservation and management measures for species belonging to the same ecosystem or associated with or dependent upon the target stocks, with a view to maintaining or restoring populations of such species above levels at which their reproduction may become seriously threatened" in Article 5(e). Mechanisms to apply the precautionary approach, as called for in Article 5(c) are specifically articulated in Article 6 of UNFSA and an entire annex (Annex II). In many ways the BBNJ agreement could build on such a model to reflect modern principles, with more specific articles and annexes articulating requirements and guidelines. It could simultaneously address a clear gap in UNFSA which is how States parties are to give effect to the general principle in UNFSA of protecting biodiversity in the marine environment and make it applicable across all sectors and regions. This gap filling could be accomplished, for instance, by building on Article 6 of the Свр (integration via, for example, sectoral, cross-sectoral/regional biodiversity strategies and action plans) and Article 8 (in-situ conservation of nature) described above.

\section{Requirements for Applying an Ecosystem Approach}

UNFSA sets out the basic requirements for an ecosystem approach in Article 5, which includes, among other things, a) assessing the impacts of fishing, other human activities, and environmental factors; b) adopting where necessary measures for species belonging to the same ecosystem or associated with or dependent upon the target stocks; c) minimizing pollution, waste, discards, and other fishing impacts through measures including the development and use of selective, environmentally safe, and cost-effective fishing gear and techniques; and d) protecting biodiversity in the marine environment. Similar requirements for applying an ecosystem approach that would be applicable to other (including sectoral) organizations could also be included in the new вBNJ agreement.

3. Requirements for Applying a Precautionary Approach

In Article 5(c), UNFSA identifies the precautionary approach as a general principle that should be applied and then elaborates on this directive in Article 6 ("Application of the precautionary approach") as well as Annex II ("Guidelines for the Application of Precautionary Reference Points in Conservation and Management of Straddling Fish Stocks and Highly Migratory Fish Stocks"). Article 6 clarifies that implementing the precautionary approach means that "States shall be more cautious when information is uncertain, unreliable or inadequate. The absence of adequate scientific information shall not be used as a reason for postponing or failing to take conservation and management 
measures." These provisions could provide guidance on how the precautionary approach could be incorporated in the BBNJ agreement.

In addition, Article 6 of UNFSA provides that States should adopt "cautious conservation and management measures" for new or exploratory fisheries, which should apply until an assessment of the impact of that fishery can be adequately determined. ${ }^{81}$ The final paragraph of Article 6 details provisions for adopting emergency conservation and management measures if "a natural phenomenon has a significant adverse effect" on that stock. These two paragraphs of Article 6 could serve as a basis for the BBNJ Agreement's consideration of conservation and management measures that should be taken for new activities as well as in response to natural phenomena that have a significant adverse impact on the marine environment.

4 .

Requirements for a Science-based Approach

UNFSA sets out specific requirements for obtaining the scientific evidence needed upon which to base decisions. In addition to "assess the impacts of fishing," UNFSA Article 5 calls for coastal States and States fishing on the high seas to collect and share, in a timely manner, complete and accurate data concerning fishing activities, to promote and conduct scientific research, and to develop appropriate technologies in support of fishery conservation and management. Article 14 specifically obliges States to "ensure that fishing vessels flying their flag provide such information as may be necessary in order to fulfill their obligations under this Agreement." Article 14 further requires States to undertake their obligation in accordance with Annex I, which sets forth further requirements for data collection and sharing. Of special note is Article 14(3)'s specific reference to, and elaboration of, another vague obligation under UNCLOS for cooperation in strengthening scientific research capacity for the benefit of all. ${ }^{82}$

$81 \quad$ After such an assessment has been conducted, "conservation and management measures based on that assessment shall be implemented."

82 UNFSA, n. 11 above, Article 14(3) provides: "Consistent with Part XIII of the Convention, States shall cooperate, either directly or through competent international organizations, to strengthen scientific research capacity in the field of fisheries and promote scientific research related to the conservation and management of straddling fish stocks and highly migratory fish stocks for the benefit of all. To this end, a State or the competent international organization conducting such research beyond areas under national jurisdiction shall actively promote the publication and dissemination to any interested States of the results of that research and information relating to its objectives and methods and, to the extent practicable, shall facilitate the participation of scientists from those States in such research" (emphasis added). 
The BBNJ agreement could adopt similar measures, including through an annex, to elaborate on the duty to cooperate in scientific research (UNCLOS, Article 242), including through competent international organizations, to elaborate on the duty to publish and share data (UNCLOS, Article 244), and to give effect to Article 202 of UNCLOS, "Scientific and technical assistance to developing States," to enable protection and preservation of the marine environment.

5. Mechanisms for International Cooperation

UNFSA focuses an entire part, Part III, on "Mechanisms for international cooperation concerning straddling fish stocks and highly migratory fish stocks." Article 8 sets out (a) the duty to pursue cooperation either directly or through RFMOs, b) the duty to pursue effective conservation and management, and (c) the duty to become members/participants of the relevant RFMOs or to agree to apply the measures adopted by the relevant RFMOs. UNFSA thus establishes an obligation to act in good faith to pursue effective outcomes both directly and through RFMOs. The вBNJ agreement could do the same.

Also of relevance to BBNJ, Article 8(6) establishes a duty to consult when a proposed action by one organization with competence over living resources proposes a measure that would have a "significant effect" on conservation and management measures already established by an RFMO. To the extent practicable, such consultation "should" take place prior to the submission of the proposal to the intergovernmental organization.

Articles 8-12 of Part III further spell out the functions of RFMOs, how RFmos should conduct their decision-making process and other activities (e.g., by providing for transparency), and directs States to cooperate to strengthen existing RFMOs in order to improve their effectiveness in establishing and implementing conservation and management measures for straddling fish stocks and highly migratory fish stocks. The BвNJ agreement could build on this UNFSA example to encourage States to cooperate to strengthen existing organizations, to join and act in good faith in any relevant existing or new organizations, and to consult in the case of overlapping competencies with respect to measures that may have a significant effect on the other.

\section{Compatibility}

UNFSA sets out, in Article 7, provisions for ensuring compatibility of conservation and management measures for living marine resources in areas under national jurisdiction and the high seas. This article outlines a complex allocation of roles and responsibilities of coastal States and distant water fishing States to ensure that measures established for stocks in the high seas do not undermine 
the effectiveness of conservation and management measures taken by the other. Notably in Article 7(3), UNFSA prescribes a duty to exercise best efforts to achieve results, by providing that "in giving effect to their duty to cooperate, States shall make every effort to agree on compatible conservation and management measures within a reasonable period of time" with an option for dispute resolution proceedings.

Additionally, UNFSA sets out requirements to enable and facilitate the establishment of compatible conservation and management measures across boundaries. For example, Article 7 paragraphs 7 and 8 establish the duty of States to exchange information on measures adopted. Articles 24-26 recognize and support the special requirements of developing States. Having informed, resourced, and well-equipped States will also be critical to ensuring coordinated and compatible efforts for marine biodiversity and ecosystems that transcend national boundaries. Similar provisions in the BBNJ agreement could address at least some of the concerns of adjacent States and developing States as a whole and help boost the capability to conserve and manage straddling ecosystems and highly migratory (non-target) species. ${ }^{83}$

Through these six mechanisms, UNFSA developed practical means to give effect to the provisions of UNCLOS, including the duty of cooperation, as a way to create common practices across different regions while taking into account regional differences. ${ }^{84}$ For the B B NJ agreement, there will be a need for a similar central core of consistent obligations and action, while allowing for varying regional and developmental conditions.

\section{Challenges and Lessons Learned from UNFSA}

Incomplete Progress towards an Ecosystem Approach

Notwithstanding its many progressive elements to implement and evolve UNCLOS, UNFSA has not resolved all issues and provides examples of some hard lessons learned. Despite some significant successes, particularly with respect to target species, continuing challenges highlighted at the recent round

83 D.C. Dunn et al., "Adjacency: How Legal Precedent, Ecological Connectivity, and traditional Knowledge Inform Our Understanding of Proximity," Nereus Scientific and Technical Brief (4 April 2017), available online: <http://archives.nereusprogram.org/wp-content/ uploads/2017/04/BBNJ-Policy-brief-adjacency_v5.pdf $>$; A. Oude Elferink, "Coastal States and MPAs in ABNJ: Ensuring consistency with the LOSC," The International Journal of Marine and Coastal Law 33 (2018): 1-30.

UNFSA, $n$. 11 above, art. 8. 
of Informal Consultations for UNFSA ${ }^{85}$ relevant to biodiversity conservation include inconsistent performance of RFMOs, lack of accountability, lack of capacity and funding, and mixed priorities. ${ }^{86}$ Of particular concern for B BNJ is the inconsistent and often incomplete progress towards an ecosystem approach to fisheries that should address bycatch, pelagic habitats, and ecosystem-level impacts in an operational way; this is perceived to be particularly an issue for tuna RFMOs, which have traditionally approached fisheries management species-by-species, as opposed to on an ecosystem level. ${ }^{87}$ During the 2018 Informal Consultation, which focused on science-policy interfaces, delegates highlighted the role of scientific research to inform policy and implement the ecosystem approach, precautionary approach, and integrated approach. Several challenges were identified in "making fisheries management decisions based on the best scientific advice available" including lack of capacity, cost, ineffective communication between stakeholders, lack of data specifically tailored to the needs of policy-makers, individual challenges faced by RFMOs, ${ }^{88}$ the often slow development of national legal frameworks, including with respect to data collection, ${ }^{89}$ and the depleted state of funds in the Assistance Fund under Part VII of the Agreement. ${ }^{90}$ Indeed, it was noted that not all States were in a position to fully implement even minimum standards under international instruments, ${ }^{91}$ which should be of significant concern to all States. Regional cooperation was recognized as a key way of overcoming capacity gaps ${ }^{92}$ and the role of the UN's Food and Agriculture Organization (FAO) in providing assistance was also noted.

\section{Relevance for BвNJ}

The lack of progress towards ecosystem-based fisheries management (ЕВFM) is a significant concern for all States with an interest in marine biodiversity in ABNJ. As noted in a recent paper prepared for the International Commission

85 United Nations, "Draft Report," Thirteenth round of Informal Consultations of States Parties to the Agreement for the Implementation of the Provisions of the United Nations Convention on the Law of the Sea of 10 December 1982 relating to the Conservation and Management of Straddling Fish Stocks and Highly Migratory Fish Stocks (New York, 22-23 May 2018) UN Doc. ICSP13/UNFSA/DraftINF.2 (15 June 2018) [UNFSA informal consultation].

86 Id.

87 M.J. Juan Jordá et al., "Report card on ecosystem-based fisheries management in tuna regional fisheries management organizations," Fish and Fisheries 19(2) (2018): 321-339.

88 UNFSA informal consultation, n. 85 above, para. 23 .

89 Id., para. 24.

$90 \quad$ Id., para. 25.

91 Id., para. 32 .

92 Id., para. 24. 
for the Conservation of Atlantic Tunas (ICCAT) on behalf of the Sargasso Sea Commission,

[t]he reason for moving towards EBFM is because fisheries are dependent on the productivity of the ecosystem, and in turn fisheries have an effect on and are affected by the ecosystem. ... It is entirely possible that a fishery could be considered not to be overfished in a single-species context but overfished within the ecosystem, for example when overfishing of large predators causes food web shifts. ${ }^{93}$

The Sargasso Sea report cites Garcia in the FaO Fisheries Atlas section on "Basic Principles of Ecosystem Management" which underscores the importance of EBFM but also some of the obstacles:

The overarching principles of ecosystem-based management of fisheries ... aim to ensure that, despite variability, uncertainty and likely natural changes in the ecosystem, the capacity of the aquatic ecosystems to produce food, revenues, employment and, more generally, other essential services and livelihood, is maintained indefinitely for the benefit of the present and future generations ... to cater both for human as well as ecosystem well-being. This implies conservation of ecosystem structures, processes and interactions through sustainable use. This implies consideration of a range of frequently conflicting objectives and the needed consensus may not be achievable without equitable distribution of benefits. ${ }^{94}$ (emphasis added)

Need for a Long-term Strategy for Ecosystem-based Management Achievement of ecosystem-based management, as noted by Garcia above, requires choices in an arena of conflicting objectives where it is frequently difficult to obtain the needed consensus. Nearly 25 years after UNFSA was adopted, the need to effectively implement the ecosystem approach remains a key topic in the tuna-RFMOs regular performance reviews. Another recent study found that

93 L.T. Kell and B.E. Luckhurst, "Extending the Indicator-based Ecosystem Report Card to the Whole Ecosystem: A Preliminary Example based on the Sargasso Sea," ICCAT Doc. SCrs/2018/067, ICCAT Collective Volume of Scientific Papers 75, no. 2 (2018): 285-275 citing M. Sinclair and G. Valdimarsson, eds., Responsible Fisheries in the Marine Ecosystem (Rome: FAO and Wallingford, UK: CABI Publishing, 2003), p. 261.

94 S.M. Garcia, The Ecosystem Approach to Fisheries: Issues, Terminology, Principles, Institutional Foundations, Implementation and Outlook, FAO Fisheries Technical Paper No. 443 (Rome: FAO, 2003). 
[m]any of the elements necessary for an operational EBFM are already present, yet they have been implemented in an ad hoc way, without a long-term vision and a formalized plan.... The [tuna RFMOs] ${ }^{95}$ appear to be halfway towards implementing the ecological component of EBFM, yet it is clear that the "low-hanging fruit" has been plucked and the more difficult, but surmountable, issues remain, notably the sustainable management of bycatch. All [tuna RFMOs] share the same challenge of developing a formal mechanism to better integrate ecosystem science and advice into management decisions. ${ }^{96}$

The Informal Consultations confirmed that data collection, scientific research, and monitoring remain among key unfilled priorities within RFMOs, which are all necessary ingredients to enable science-based policy, including E вF ${ }^{97}$ As is explored immediately below, one of the major challenges to effective implementation of UNFSA and thus the achievement of sustainable fisheries is the lack of a central institutional mechanism capable of reviewing performance and adopting timely measures when needed to improve implementation and performance at the State and regional levels.

So, noting the challenges in implementing UNFSA, many of which may be shared by other sectoral organizations, we can also learn lessons for the Bв NJ agreement and identify ways that, through the в BNJ agreement, States could be better able to fulfill their rights and obligations under UNCLOS, and in so doing, potentially help to implement UNFSA.

\section{Building a Platform for Cooperation for B BNJ}

\section{Importance of Institutional Mechanisms for Cooperation}

The previous sections have described the need for giving further substantive weight to the provisions of UNCLOS with respect to the duty to cooperate to protect and preserve the marine environment, what such substantive provisions could contain, based on the provisions of the CBD, and how this might be done, by building on the example of UNFSA. This section seeks to elaborate on how the BBNJ agreement can give greater procedural weight to the duty to cooperate through the specification of institutional mechanisms at the global

95 RFMOs with the competence over tuna and other migratory species are often referred to as t-RFMOs.

96 Juan Jordá et al., n. 87 above, abstract.

97 UNFSA informal consultation, n. 85 above, para. 32 . 
and regional levels, based on the lessons learned from existing environmental agreements and regional initiatives. ${ }^{98}$

As observed by Tanaka, the specification of institutional mechanisms can enhance the implementation of the duty to cooperate by allocating responsibilities for getting a job done and through international supervision:

Considering that international co-operation is essential to advance the integrated management approach, institutionalised mechanisms for ensuring such cooperation, such as an international supervision through international institutions, become particularly important. ${ }^{99}$

One of the lessons of relevance to the BBNJ agreement negotiators is that at least some of UNFSA's shortcomings may be attributed to its lack of a globallevel institutional mechanism with sufficient supervisory powers to "prevent disparate practices in different subregions or regions" from emerging. As noted by Young and Friedman, the "ad hoc arrangements for coordination" adopted in UNFSA "encourages states to apply guiding principles and approaches within existing bodies without engaging in systematic or binding norm development. Attempts to develop a coherent set of practices through processes such as the joint meetings of the five tuna RFMOs initiated in Kobe, Japan, in 2007, have not progressed." 100 The new agreement can enhance implementation by providing a venue for "interregime learning and cooperation."101

Similar lessons were learned from early wildlife treaties that proved relatively ineffectual because, among other things, none of them established a system of administration to monitor and oversee their enforcement. ${ }^{102}$ Some, like the Convention on Nature Protection and Wildlife Preservation in the Western Hemisphere (Western Hemisphere Convention), became known as "sleeping treaties" that had been allowed to drift from the forefront of their parties attention and, in consequence, failed to have as much practical impact as they would have had if given the proper encouragement. ${ }^{103}$ Submission of regular

98 Tanaka, n. 44 above, p. 24.

99 Id.; see also Harden-Davies and Gjerde, n. 13 above.

100 M.A. Young and A. Friedman, "Biodiversity beyond national jurisdiction: Regimes and their interaction," AJIL Unbound 112 (2018): 123-128, p. 128, DOI: 10.1017/aju.2018.47.

101 Id., p. 126.

102 S. Lyster and H.R.H. Prince Philip, International Wildlife Law: An Analysis of International Treaties Concerned with the Conservation of Wildlife (Cambridge: Cambridge University Press, 1985), p. 301.

103 Convention on Nature Protection and Wildlife Preservation in the Western Hemisphere, 12 October 1940, entered into force 1 May 1942, OAS Treaties Series, No. 31; 161 United Nations Treaty Series 193. 
reports and regular meetings of parties to review implementation and make recommendations can avoid sleeping treaties. According to Lyster:

The treaties which have achieved the greatest level of compliance are, by and large, those which keep their Parties active, have a central administrative body to oversee enforcement and have some means of chastising Parties which do not comply with their treaty obligations ... just by requiring its Parties to meet regularly to review its implementation, a treaty can ensure that it stays on the foremost of its Parties attention. ${ }^{104}$

If it is to achieve its full potential, maintain its relevance, and carry out the principles and obligations described above, the new agreement would accordingly need to adopt institutional mechanisms that include at least four key elements: a central administrative body, a science-policy advisory mechanism or body, regular review of implementation, and power to adopt binding decisions.

\section{Implications for Institutional Arrangements for the B BNJ Agreement}

With respect to institutional arrangements, there was general consensus at the PrepCom that there needed to be at least three core bodies established by the BBNJ agreement: a decision-making body, a scientific and/or technical body, and a secretariat. ${ }^{105}$ of course, additional subsidiary bodies could be established (which could focus on, for example, monitoring compliance or overseeing financial components) and, indeed, may be necessary in order to best carry out the objectives of the agreement. This article focuses only on the three core bodies, mentioned above, which were included in the PrepCom report.

\section{Three Potential Models: Regional, Hybrid, and Global}

The delegates' vision for the specific functions that each of these bodies could undertake varied a great deal and is inextricably related to the scale at which States believe the new BвNJ agreement should operate. There were generally three models that States used to describe the operational scale for the new BBNJ agreement: global, hybrid, and regional. It should be noted that there was no single definition for these three models; they are perhaps best understood as existing along a spectrum of options. On one end of the spectrum, an extreme "regional model" could be envisaged with the ввNJ agreement being carried out exclusively by existing sectoral and/or regional institutions (to include regional sectoral bodies and global sectoral bodies); under this regional

104 Lyster and H.R.H., n. 102 above, p. 301.

105 PrepCom Report, n. 28 above, pp. 16-17. 
model, the institutional needs would be minimal. Parties to the agreement might have regular meetings to report on their progress towards implementing the BвNJ agreement, but there would be no need for a decision-making body or a scientific body to carry out the agreement. With this in mind, the regional model can effectively be viewed as the status quo of ocean governance, with perhaps some additional, broad guidance provided by the new BвNJ agreement. ${ }^{106}$

On the other end of the spectrum of institutional arrangements, the "global model" could be envisaged as the creation of a new body which could more actively and directly carry out the objectives of the new BBNJ agreement. Global model proponents support the establishment of, at a minimum, the three core bodies (decision-making body, scientific/technical body, and secretariat), and it is envisioned that the decision-making body would be empowered to take decisions that are both specific and binding upon its parties. ${ }^{107}$ Many proponents of the global model specifically advocate that the new ввNJ agreement should empower the new ввNJ body to establish high seas MPAs and approve EIAs: this would require not only a decision-making body, but also a robust scientific committee capable of reviewing MPA and EIA proposals and a secretariat that could help to coordinate the consultation process. ${ }^{108}$

Somewhere in the middle of this spectrum lies the hybrid approach. Many delegates during the PrepCom advocated for the adoption of a hybrid approach - a model of institutional arrangements that would advance ocean governance more than the status quo regional approach, but would fall short of the centralized global-level decision-making powers envisioned under the global approach, at least for certain issues such as ABM Ts other than M PAs. ${ }^{109}$

106 The Pew Charitable Trusts, "Towards a Global Solution for High Seas Conservation," Fact Sheet (March 2017), available online: <http://www.pewtrusts.org/-/media/assets/2017/03/ highseas_towards_a_global_solution_for_high_seas_conservation.pdf $>$.

107 A. Friedman et al., "Protecting marine biodiversity in areas beyond national jurisdiction: Institutional considerations for a new international agreement under the United Nations Convention on Law of the Sea," in The Law of the Sea and Emerging Issues, eds., G.(J.) Xue and J. Zheng (Shanghai: China Democracy and Legal System Publishing House, 2018).

108 See, e.g., "Costa Rica and Monaco joint submission on marine protected areas" (31 August 2016) submitted in response to a letter from the Chair of the PrepCom dated 18 December 2015 inviting delegates to submit their views on the elements of a draft text on an international legally binding instrument under UNCLOS, available online: <http://www.un.org/ depts/los/biodiversity/prepcom_files/Costa_Rica_Monaco_BBNJ_Submission_MPAs. pdf $>$.

109 See, e.g., IISD Reporting Services, "Summary of the Third Session of the Preparatory Committee on Marine Biodiversity Beyond Areas of National Jurisdiction: 27 March-7 April," 
While there was a divergence of views with respect to the precise functions and duties the ввNJ agreement would establish under the hybrid model, there was general agreement that it would require a decision-making body, a scientific/technical body, and a secretariat. ${ }^{110}$

Mapping States' positions on institutional arrangements for the new вBNJ agreement can be challenging, even with the understanding that there is a spectrum of options. An excellent example of this challenge can be found in the submission on behalf of the Pacific Small Island Developing States (PSIDS) to the PrepCom. ${ }^{111}$ The PSIDs' position on institutional arrangements, at least during the PrepCom, envisioned a "comprehensive global regime to better address the conservation and sustainable use of ввNJ," supported by a globallevel decision-making body, a secretariat, a scientific and technical body, a compliance committee, and a finance and administration committee. ${ }^{12}$ At the same time, the PsiDs' submission provides for a strong regional component and envisions that regional bodies would play a critical role in implementing the new ввNJ Agreement. ${ }^{113}$ This highlights an important observation; that regional-level and global-level institutional arrangements are not mutually exclusive and could, in fact, complement one another.

\section{Strengthening - Not Undermining - Existing Organizations}

One consideration that may influence institutional choices is the provision in Resolutions 69/292 and 72/249 that this "process and its result should not undermine existing relevant legal instruments and frameworks and relevant global, regional and sectoral bodies."114 However, as some have suggested, the phrase "not undermine" was seemingly chosen for its political malleability there can be general agreement that the new instrument should not undermine existing ones, without a precise understanding of exactly what it means to not undermine, or, perhaps more exactly, what would constitute undermining one

Earth Negotiations Bulletin 25, no. 129 (10 April 2017), available online: <http://enb.iisd. org/download/pdf/enb25129e.pdf>.

110 PrepCom Report, n. 28 above, pp. 15-16.

111 "Psids Submission on Institutional Arrangements" (5 December 2016) submitted in response to the Chair's invitation made at the second session of the PrepCom, as reflected in para. 11 of his overview of the second session of the PrepCom, available online: <http:// www.un.org/depts/los/biodiversity/prepcom_files/streamlined/PSIDS_Submission_ dec_2016.pdf>.

112 Id.

113 Id.

$11472 / 249$, n. 10 above, para. 7. 
of these organizations. ${ }^{115}$ For the new agreement to achieve its stated goal of conserving and sustainably using marine biological diversity of areas beyond national jurisdiction, it must improve upon the status quo; it is clear that the meaning of the term "not undermine" should be interpreted in a way that advances that aim.

Indeed, rather than seeking to exclude particular sectors or otherwise viewing the new instrument through a negative lens, the focus could be on how the new ввNJ agreement can enable, facilitate, and even strengthen existing global, regional, and sectoral bodies and instruments in fulfilling their responsibilities under UNCLOS to protect and preserve the marine environment. In addition to mainstreaming core biodiversity, ecosystem, and precautionary concepts into the functions of sectoral organizations and enabling national and regional capacities to do the same, it becomes clear that improved processes for consultation and cooperation are needed. In particular, these cooperative and consultative processes are critical to ensure that marine biodiversity and ecosystems are not degraded by the actions of any one sector or regional institutions and that existing instruments are not undermined, either by each other or by factors such as illegal, unreported, or unregulated fishing or other unmanaged/uncontrolled activities.

\section{A Common Platform for Conservation}

Enabling Ecosystem-based Management as a Shared Goal A central organizing theme for enhancing cooperation and coordination could be ecosystem-based management, based on science and the precautionary principle, for the purposes of conserving and sustaining marine biodiversity and its components of genes, species, habitats, and ecosystems. The medium for cooperation, in addition to consultations and exchange of information at annual conferences of parties, could be the development of sectoral as well as cross-sectoral, regionally-based biodiversity strategies and action plans. Such biodiversity strategies and action plans could build upon Article 6 of the СвD and be based on the general principles as agreed in Article 5 of UNFSA to a) assess the impacts of the specific sectoral activity, other human activities, and environmental factors, b) adopt, where necessary, measures for protecting affected species, habitats and ecosystems, c) minimize pollution, waste, discards,

115 Z. Scanlon, "The art of "not undermining": Possibilities within existing architecture to improve environmental protections in areas beyond national jurisdiction," ICES Journal of Marine Science (2017), DOI: 10.1093/icesjms/fsx209. Discussion on the interpretation of "not undermining" can be found above under "Application of the Term 'Undermine." 
and other impacts through measures including area-based management tools, and d) protect biodiversity in the marine environment.

States have indicated their desire to create a BBNJ agreement that does just that - there was general consensus during the PrepCom that both the ecosystem and the precautionary approach could be included as "General principles and approaches" in the new agreement. ${ }^{116}$ This section concludes with a look ahead to key considerations for the institutional framework.

\section{Roles for a Global Institution}

In considering the type of institutional mechanisms, it has often been said that "form follows function." Hence it may be helpful to explore what some of the values and functions a global institution might provide compared to what is presently possible. A ввNJ agreement could establish an ongoing system of governance, both by providing guidance to existing institutions and by creating new ones, defining their powers and decision-making rules, establishing procedures to adopt and amend substantive rules, and providing methods to resolve disputes. An important benefit would be to enable States to address issues in a purposive, rational manner rather than an ad hoc, patchwork approach. A regular meeting or conference of the parties could overcome the obstacles to cooperation that currently inhibit a more integrated and coherent approach to management. Such meetings of parties could promote reciprocal implementation by allowing States to delineate precisely what each party is expected to do, provide clarity on applicable norms, and encourage all countries to cooperate so efforts by one country are not undermined by another. Such functions can build trust, improve knowledge, reduce misperceptions, and increase legitimacy.117

Such a decision-making body could, for example, be given a leading role in designating MPAs, considering EIAS, and reviewing reports to assess progress. It could also provide guidance to States parties with respect to rules, standards, and recommended practices and procedures for sectoral Авмтs, strategic environmental assessments, and broader-scale regional planning and integrated management initiatives. This conference or meeting of parties could play a key coordinating role by ensuring prior notification, consultation, transparency, participation, and inclusive planning. It could also help to bring in the goals and priorities of other conservation agreements and bodies, such as CITES,

116 PrepCom Report, n. 28 above, p. 9.

117 Gjerde, n. 9 above, p. 379. Inspiration for this analysis comes from D. Bodansky, The Art and Craft of International Environmental Law (Cambridge, MA: Harvard University Press, 2010), pp. 136-153. 
СвD, and CMS and related agreements, in order to enhance their effectiveness and ensure that their efforts are not undermined by activities managed by neighboring or overlapping sectoral organizations, and ensure that sectoral and regional area-based conservation measures adopted pursuant to the вв $\mathrm{NJ}$ agreement are respected globally.

\section{Strengthening Regional and Sectoral Outcomes}

A review of the experience of the Sargasso Sea Project may help to illustrate the value of such a global approach for strengthening the current regional/ sectoral approach. ${ }^{118}$ Currently, there are just a handful of international organizations in the Sargasso Sea with some sectoral management competence: two RFMOs, one advisory fisheries body, the IMO and the ISA. ${ }^{119}$ None of these organizations focus on comprehensive conservation of marine biodiversity or ecosystems. Each institution focuses on its respective sector with little or no reference to the work of other sectoral bodies or neighboring regional bodies. The nearest Regional Seas Programme, which covers the Wider Caribbean Region, does not reach as far north as Bermuda, the heart of the Sargasso Sea, or extend to ABNJ. There is thus no mechanism for coordinating between the various sectors to ensure the conservation of important habitats and ecosystems. One sector's failure to recognize the work of another is an unfortunate example of how the fractured sectoral approach appears to be undermining efforts to use the precautionary principle and protect areas of significant biodiversity. ${ }^{120}$ The region, like most others, also lacks a mechanism to consider cumulative impacts from different sectors and the aggravating factor of climate change. ${ }^{121}$

In response to the limited mechanisms and capacities of sectoral institutions, the Sargasso Sea Project was launched as an ad hoc initiative to bring key governments and other stakeholders together. The Project's goal was to collectively pursue those measures that could be taken to more comprehensively

118 Freestone, n. 43 above; Friedman et al., n. 107 above; K. Gjerde, O. Varmer and K. Liljestrand, "The Sargasso Sea: An innovative approach to governance in areas beyond national jurisdiction," in Frontiers in International Environmental Law: Oceans and Climate Challenges. Essays in Honour of David Freestone (Leiden: Brill, in review); D. Freestone, "The Sargasso Sea Alliance: Working to protect the 'Golden Floating Rain Forest of the Ocean," Environmental Policy and Law 44 (2014): 151-158.

119 Those RFMos are the International Commission for the Conservation of Atlantic Tunas and the Northwest Atlantic Fisheries Organization; the advisory fisheries body is the Western Central Atlantic Fishery Commission.

120 Gjerde et al., n. 118 above.

121 Id.; Freestone, n. 118 above. 
conserve this ecologically and biologically important area and to shine a light on the obstacles to progress. The results have copiously demonstrated the need for a global level agreement to address the reluctance of some States in some fora to embrace proactive conservation measures, despite calls for the application of the best available science and the adoption of a precautionary approach/principle in most modern international legal instruments and declarations. ${ }^{122}$ The new agreement could facilitate cooperation and coordination to enable ecosystem-based management at a regional level by establishing or designating regional coordinating bodies while ensuring strong global support.

\section{Conclusion}

The current single-sector approach to governing the global ocean commons has presented significant challenges and, ultimately, has failed to uphold one of the central requirements of UNCLOS - to protect and preserve the marine environment. States have responded to the multitude of growing pressures that threaten the vitality of marine ecosystems by calling for a comprehensive regime to better address B BNJ conservation and sustainable use. The development of the BBNJ agreement is a once-in-a-generation opportunity to address these governance challenges and affect positive change, not only for the marine environment, but also for the States and people who depend upon the ocean.

Gaps in implementation have arisen because UNCLOS sets a framework that specifies but does not elaborate States' duties to protect and preserve to protect the marine environment. Post-UNCLOS innovations have elaborated on the duty to cooperate to include a broader concept of the marine environment - the wealth and diversity of genes, species, habitats, and ecosystems that inhabit it - and recognized both the intrinsic value of this biodiversity as well as its role in supporting essential ecosystem services that sustain life on earth. This broader concept requires a more integrated and coherent approach to management that can account for the full range of activities and effects on the marine environment. The B BNJ agreement thus provides the opportunity to articulate how States are to give effect to the duty to protect and preserve the marine environment including its biodiversity and associated ecosystems and to advance the integrated cross-sectoral institutional mechanisms needed to ensure its implementation.

122 Freestone, id. 
To achieve this, States will need to adopt more specific global rules and standards, and recommended practices and procedures as envisaged in Article 197, and to elaborate the requirements for effective institutional mechanisms at the global and regional levels. The ввNJ agreement could draw inspiration from, for example, Article 6 of the Свр (integration via, for example, sectoral, cross-sectoral/regional biodiversity strategies and action plans) and Article 8 (in-situ conservation of nature) (see "Building on UNCLOs" above). It could, as was done in the UNFSA (see "What Can Be Learned from UNFSA?" above) further articulate requirements for applying an ecosystem approach that would be applicable to States parties' conduct in all organizations. It could set out the underpinning basis for deploying a science-based approach as well as establish or designate and strengthen institutions charged with enhancing cooperation and coordination. And most importantly, it could also establish a global institution such as COP to implement certain requirements directly and to collectively review, coordinate, facilitate, and provide direction to other institutions, regions, and States parties to ensure even progress (see "Building a Platform for Cooperation for BBNJ" above).

That the BBNJ agreement will take the form of a new implementing agreement to UNCLOS is clear from UNGA Resolution 72/249. UNFSA offers a model for how an implementing agreement under UNCLOS can give greater effect to the rights and responsibilities of States in relation to marine life. It also highlights lessons, both positive and negative, that the negotiators of the вв $\mathrm{NJ}$ agreement can draw upon as well as challenges that they could potentially help to address. For example, with respect to compatibility, similar provisions to UNFSA could address at least some of the concerns of adjacent States and developing States as a whole and help boost capacity all around to conserve and manage straddling ecosystems and highly migratory (non-target) species. The charge of the BвNJ agreement to be interpreted and applied in a manner that would not undermine existing instruments, frameworks, and bodies should be viewed as an opportunity and not a challenge.

The ввNJ agreement provides the opportunity to establish the institutional mechanisms to support active implementation and adaptation in an increasingly crowded and fundamentally changing ocean. This rare chance should be seized upon to enable greater coherence across all bodies, complement existing agreements and processes, while ensuring that the actions of one body do not undercut those of another. An institutional framework should include at least four key elements: a central administrative body, a scientific advisory mechanism or body, regular review of implementation, and the power to adopt binding decisions. 
In short, the вBNJ agreement has the potential to create a lasting platform for realizing the vision of the UNCLOS negotiators for promoting the study, protection, and preservation of the marine environment while also enhancing the conservation of living marine resources, ensuring that marine resource use is indeed sustainable, and enabling more equitable use for the benefit of all beyond national boundaries. An ambitious agreement under UNCLOS could help to solidify the status of UNCLOS as the "constitution for the ocean" by enabling it to evolve to meet the demands of the ever-changing ocean and governance environments. As eloquently stated by Rayfuse and Warner,

In view of escalating threats to the oceans from existing and emerging uses and from the impacts of climate change, transformation to a legal regime better suited to integrated, cross-sectoral management and preservation of vital ocean ecosystem services and resilience may no longer be a luxury, but rather a necessity. ${ }^{123}$

123 R. Rayfuse and R. Warner, "Securing a sustainable future for the oceans beyond national jurisdiction: The legal basis for an integrated cross-sectoral regime for high seas governance for the 21st century," The International Journal of Marine and Coastal Law 23 (2008): 399-421. 